\title{
The taxonomy and zoogeography of the family Trachyleberididae (Crustacea: Ostracoda) from the Equatorial Continental Shelf of Brazil
}

\author{
J. C. COIMBRA ${ }^{1}$, M. I. F. RAMOS ${ }^{2}$, R. C. WHATLEY ${ }^{3} \&$ C. T. BERGUE ${ }^{1}$ \\ ${ }^{1}$ Instituto de Geociências, UFRGS, Caixa Postal 15001, CEP 91501-970, Porto Alegre, RS, Brazil (e-mail: joao.coimbra@ufrgs.br: \\ hussardo@yahoo.com.br). \\ ${ }^{2}$ Museu Paraense Emílio Goeldi, Campos de Pesquisa, CPPG, CP 399, Av. Perimetral, 1901, Terra Firme CEP 66077-530, Belém, Pará, Brazil \\ (e-mail:mramos@museu-goeldi.br). \\ ${ }^{3}$ Micropalaeontology Unit, Department of Geology, University of Wales, Aberystwyth SY23 3DB, UK (e-mail: riw@aber.ac.uk).
}

\begin{abstract}
A study of the family Trachyleberididae Sylvester-Bradley from the Equatorial Continental Shelf of Brazil (almost $1400 \mathrm{~km}$ in length) revealed the presence of five new species, which are described herein. These are: Cletocythereis atlantica, Cativella paratranslucens, Cativella reticulocostata, Henryhowella tuberculoclaviforma and Australimoosella polypleuron. Two sub-species of the genus Costa, C. variabilicostata brasiliensis subsp. nov. and C. variabilicostata aff. recticostata Bold, are placed within the variabilicostata group. The genus Neocaudites is represented by two species, $N$. subimpressus Edwards and N. triplistriatus Edwards, originally described from the Upper Miocene and Pliocene of the Duplin Marl, North Carolina, USA. The genus Puriana is represented by $P$. convoluta Teeter and $P$. variabilis Chukewiski \& Purper, described originally from Belize (British Honduras) and the Brazilian coast, respectively. The geographical distribution of the studied fauna, reveals the presence of two assemblages on the Equatorial Continental Shelf of Brazil, a Northwest and a Southwest assemblage, separated by the area of discharge of the Amazon and Pará rivers and each with its distinctive oceanographical and sedimentological characteristics. J. Micropalaeontol. 23(2): 107-118, November 2004.
\end{abstract}

\section{INTRODUCTION}

This contribution is part of a larger study of the Recent marine Ostracoda of the Brazilian margin. It is concerned solely with the taxonomy and zoogeography of the family Trachyleberididae from the Equatorial Continental Shelf. The first study of Ostracoda from the Brazilian Equatorial Shelf began with the classical study of Brady (1880), but only in the last 25 years has important modern research been undertaken in this extensive geographical area (almost $1400 \mathrm{~km}$ in length). Thus, studies in the same area, based on the genera Puriana, Pseudoceratina, Paracytheridea, Caudites, Orionina, Kangarina, Cornucoquimba, Coquimba, Krithe, Callistocythere, Auradilus and Radimella were conducted by Chukewiski \& Purper (1985a, b), Ornellas \& Coimbra (1985), Coimbra \& Ornellas (1986, 1987, 1989), Purper \& Ornellas (1987a, b), Medeiros \& Coimbra (1989), Ramos (1994, 1996), do Carmo \& Sanguinetti (1995), Coimbra et al. (1995) and Fauth \& Coimbra (1998). Coimbra et al. (1999a) undertook an overview of the origin and zoogeography of the Holocene ostracods from this part of the Brazilian Shelf and Coimbra et al. (1999b) studied the family Cytheruridae from the same area. Coimbra \& Carreño (2002) studied the distribution patterns of the family Bairdiidae along the Equatorial Shelf of Brazil. Finally, Coimbra \& Fauth (2002) and Coimbra \& do Carmo (2002), described new species for the families Bythocytheridae and Pectocytheridae, and the subfamily Coquimbinae, respectively.

\section{STUDY AREA}

The area studied embraces the Brazilian Continental Shelf located between Orange Cape $\left(4^{\circ} 24^{\prime} \mathrm{N}\right)$, Amapá State and São Roque Cape ( $5^{\circ} 29^{\prime}$ S), Rio Grande do Norte State (Fig. 1). The area extends from the coastline out to $200 \mathrm{~m}$, with a median declivity of $0.1^{\circ}$ and a maximum width of $330 / 350 \mathrm{~km}$ in the mouth of Amazonas/Pará rivers (Martins \& Coutinho, 1981). Thirty-one samples have been collected from deeper areas, 15 located to the SE and 16 to the NW of the Amazon estuary (Fig. 1).

\section{Sedimentology}

Martins et al. (1975) recognized two physiographical provinces in the shelf of this area: (1) Orange Cape-Parnaíba River Delta; and (2) Parnaíba River Delta-Cape São Roque (Fig. 2).

Orange Cape-Parnaíba River Delta. According to previous studies, terrigenous sediments in the inner shelf and reworked sands in the middle and outer shelf are of common occurrence. According to Martins \& Coutinho (1981) and Martins (1974), the terrigenous sediments to the north of the mouth of the Amazon/Pará rivers are essentially pelitic on the inner shelf, reaching a maximum depth of $30 \mathrm{~m}$.

The middle and outer shelf are dominated by a sandy sequence that changes from quartz to bioclastics, extending out to the slope. Calcareous facies on the outer shelf are poorly developed, due to the fluvial influence, with fluvial deposits covering the carbonatic facies. The presence of oolites on the shelf can be explained by the presumed presence of an ancient hypersaline lagoon environment.

From southeast of the mouth of the Pará River to that of the Parnaíba River, the dominant quartzose sands are completely different petrographically from those derived from the Amazon River. In this facies, there is a high level of reworking and low fluvial contribution, at least since the last sedimentary cycle. Only at the mouths of the Gurupi and Parnaíba rivers are there fluvial influences. Carbonate sediments, according to Kowsmann \& Costa (1979), frequently reach $\mathrm{CaCO}_{3}$ levels higher than $95 \%$, recorded as a continuous band on the outer 


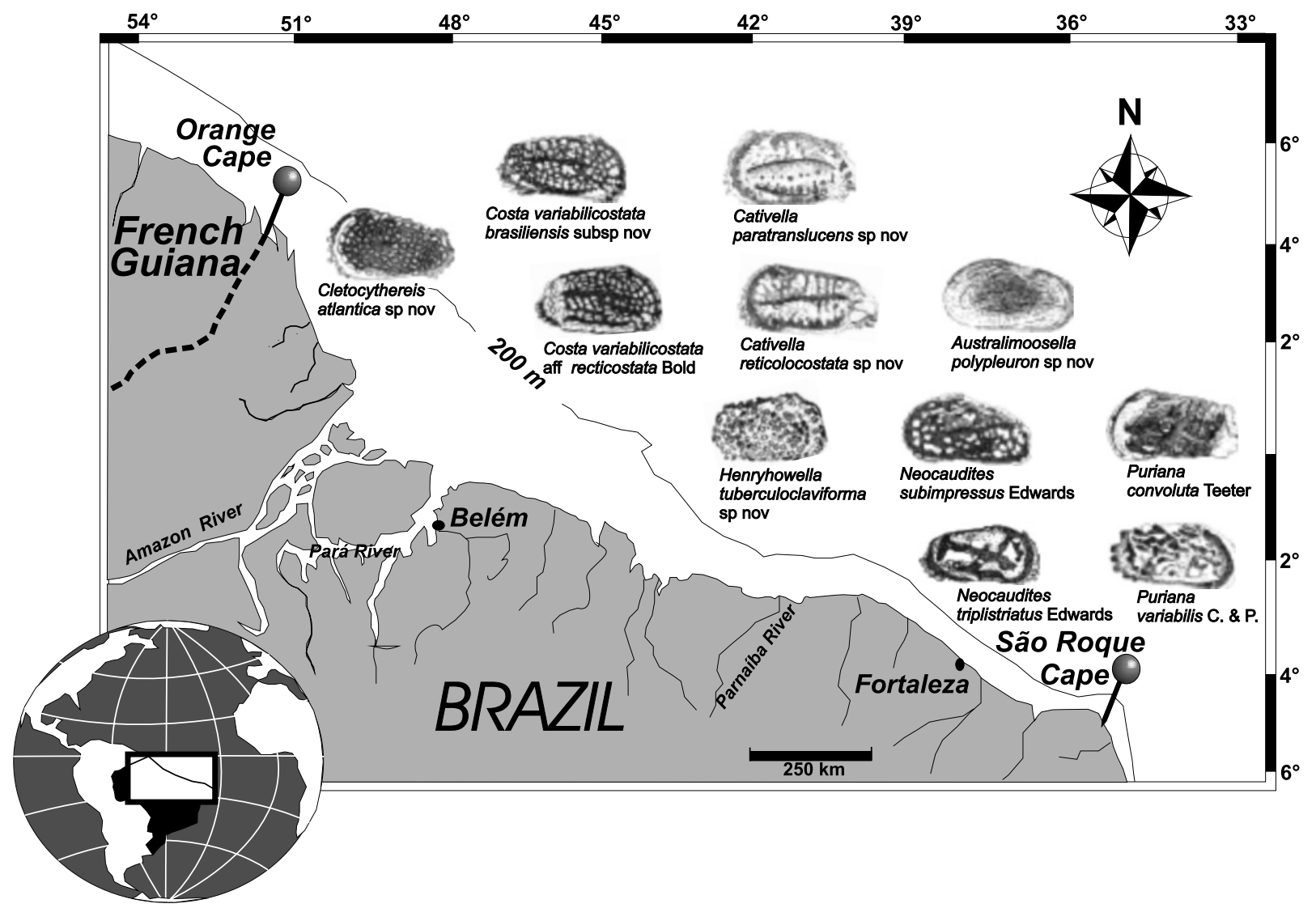

Fig. 1. Map of the study area and the species of Trachyleberididae.

shelf. These organic carbonate sediments are derived from algae, coralline algae, benthic foraminifers and molluscs. The largescale distribution of algal reefs can be explained by the low terrigenous contribution to this part of the Equatorial Continental Shelf.

Parnaíba River Delta-Cape São Roque. The continental shelf gradually narrows towards São Roque Cape $\left(5^{\circ} 29^{\prime} \mathrm{S}\right)$ and the carbonate contribution is higher than the terrigenous. Accord- ing to Kowsmann \& Costa (1979), the $\mathrm{CaCO}_{3}$ level is higher than $75 \%$ for almost the entire area. The terrigenous component is essentially constituted by reworked sands and it is better developed on the Ceará coast. The predominance of carbonate in this area is due to the depth of the shelf $(<60 \mathrm{~m})$, relatively warm water, semi-arid climate and solid substrate, permitting the proliferation of a calcareous benthic fauna.

The carbonate sediments are mainly constituted by sand and gravel, with coralline algae from Lithothamnium, Lithophyllum

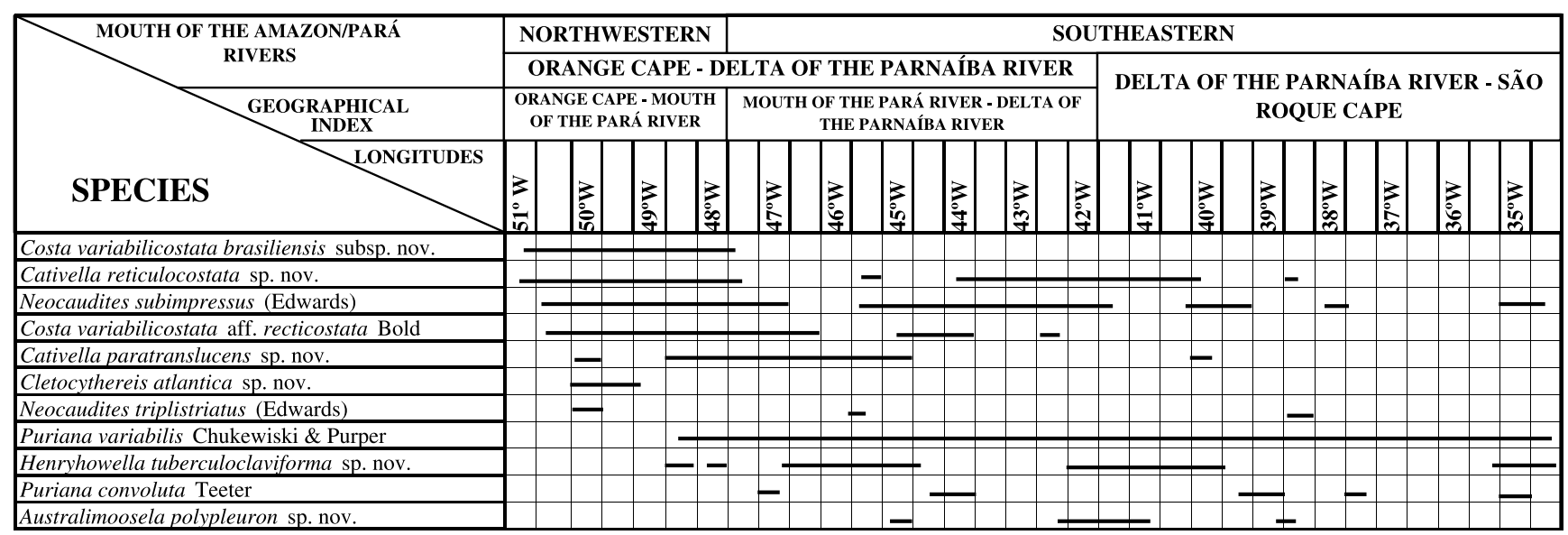

Fig. 2. Zoogeographical distribution of Trachyleberididae along the Brazilian Equatorial shelf. 
or Halimeda. The presence of molluscs and/or benthic foraminifers is restricted to particular areas (Kowsmann \& Costa, 1979). Ancient and modern sediments can be mixed in this area and the phenomenon of iron staining is taken to represent exposure during the Wisconsian Regression.

\section{Oceanography}

The Equatorial South Atlantic Current reaches the Brazilian continental margin at Cape São Roque, where it divides into the Guianas and Brazil currents, the former flowing northwestwards and the latter to the southeast. The Equatorial Continental Shelf is influenced by the Guianas Current that, according to Martins (1984), flows NW, with a mean temperature of $27^{\circ} \mathrm{C}$, a salinity of $36 \%$ and maximum velocity of 4.0 knots. The influence of the Amazon River is dominant, its enormous freshwater discharge radically changing the physico-chemical characteristics of the oceanic area adjacent to the estuary.

\section{MATERIAL AND METHODS}

The 339 samples, on which this study is based, were collected by Van Veen grab during a series of cruises. 177 samples are from REMAC Project (Legs 4, 5, 5A and 6) and 162 are from the Geomar I, II, III Project. Of these, 207 yielded ostracods and 132 were barren. The data of the samples, with the studied ostracod families, are shown in Figure 2. The preparation of the samples was by standard methods. Specimens were illustrated using the Phillips SEM from the Departamento de Metalurgia at UFRGS.

The numbers of specimens in the systematic descriptions are represented in the following manner: very abundant $>300$; abundant 101-300; common 51-100; frequent: 21-50; rare: 15-20. The following abbreviations are used in the species descriptions: LV, left valve; RV, right valve; $\mathrm{C}$, carapace. The type material used in this study is held in the collections of the 'Museu de Paleontologia', Universidade Federal do Rio Grande do Sul, Section of Ostracoda, to which the prefix MP-O refers.

\section{SYSTEMATIC DESCRIPTIONS}

Suborder Podocopina Sars, 1866

Superfamily Cytheracea Baird, 1850

Family Trachyleberididae Sylvester-Bradley, 1948

Subfamily Trachyleberidinae Sylvester-Bradley, 1948 Genus Henryhowella Puri, 1957

Henryhowella tuberculoclaviforma sp. nov. (Pl. 1, figs 1-6)

Derivation of name. L. With reference to the clavate spines with which this species is covered.

Diagnosis. A large sub-rectangular species of Henryhowella with strong marginal rims and an ornament of strong clavate tubercles.

Holotype. Female RV, MP-O-1761.

Material. Abundant.
Locality and horizon. Project REMAC, Leg 6, sample 3699, lat. $02^{\circ} 21^{\prime} \mathrm{S}-$ long. $39^{\circ} 56^{\prime} \mathrm{W}, 35 \mathrm{~m}$. Recent.

Description. Large. Thick-shelled. Sub-rectangular in lateral view. Anterior margin widely rounded with numerous short, blunt marginal denticles. Posterior margin with blunt apex at mid-height in RV and truncated in LV. Dorsal margin with prominent anterior hinge ear; straight, but rendered corrugate by ornament and gently inclined towards the posterior. Ventral margin straight. Strong marginal rims surround the end margins, separated from the lateral surface by distinct crescentic furrows. Entire carapace covered by large, irregular, clavate tubercles, superimposed upon an underlying reticulation. The ornament largely masks the subcentral tubercle. Eye tubercle large and prominent. In dorsal view both valves are biconvex with a distinct depressed central area. Internal characters and sexual dimorphism as for the genus.

\section{Dimensions (mm).}

Holotype

Female RV, MP-O-1761 $\quad 0.88 \quad 0.54$

Paratypes

Female LV, MP-O-1760 $\quad 0.86 \quad 0.57$

Female C, MP-O-1762 $\quad 0.86 \quad 0.55$

Male LV, MP-O-1763 $\quad 0.87 \quad 0.51$

Male RV, MP-O-1764 $0.89 \quad 0.52$

Distribution. Recent sediments from the Equatorial Shelf of Brazil. In the present study it occurs in the following samples: Leg 5, samples 3430, 3433, 3441, 3459; Leg 6, samples 3607 , 3608, 3637, 3686, 3690, 3699, 3743, 3754, 3756; Geomar I, samples 21, 24, 29, 33, 34; Geomar II, sample 101; Geomar III, sample 192.

Remarks. This species differs from all other species of the genus known to the authors in the nature of its ornament of clavate tubercles.

Genus Costa Neviani, 1928

Costa variabilicostata Bold, 1963

Costa variabilicostata brasiliensis subsp. nov. (Pl. 1, figs 7-9)

Derivation of name. With reference to its occurrence in Brazilian waters.

Diagnosis. A new sub-species of Costa variabilicostata, ornamented with strong ribs and intercostal reticulae, the latter being secondary papillate in the solum. Three large nodes occur on the anteromarginal rib antero-ventrally and dorsal rib is sinuous.

Holotype. LV, MP-O-1765.

Material. Common.

Locality and horizon. Geomar II, sample 97, lat. $2^{\circ} 24^{\prime}$ N-Long. $48^{\circ} 38^{\prime} \mathrm{W}, 77 \mathrm{~m}$. Recent. 

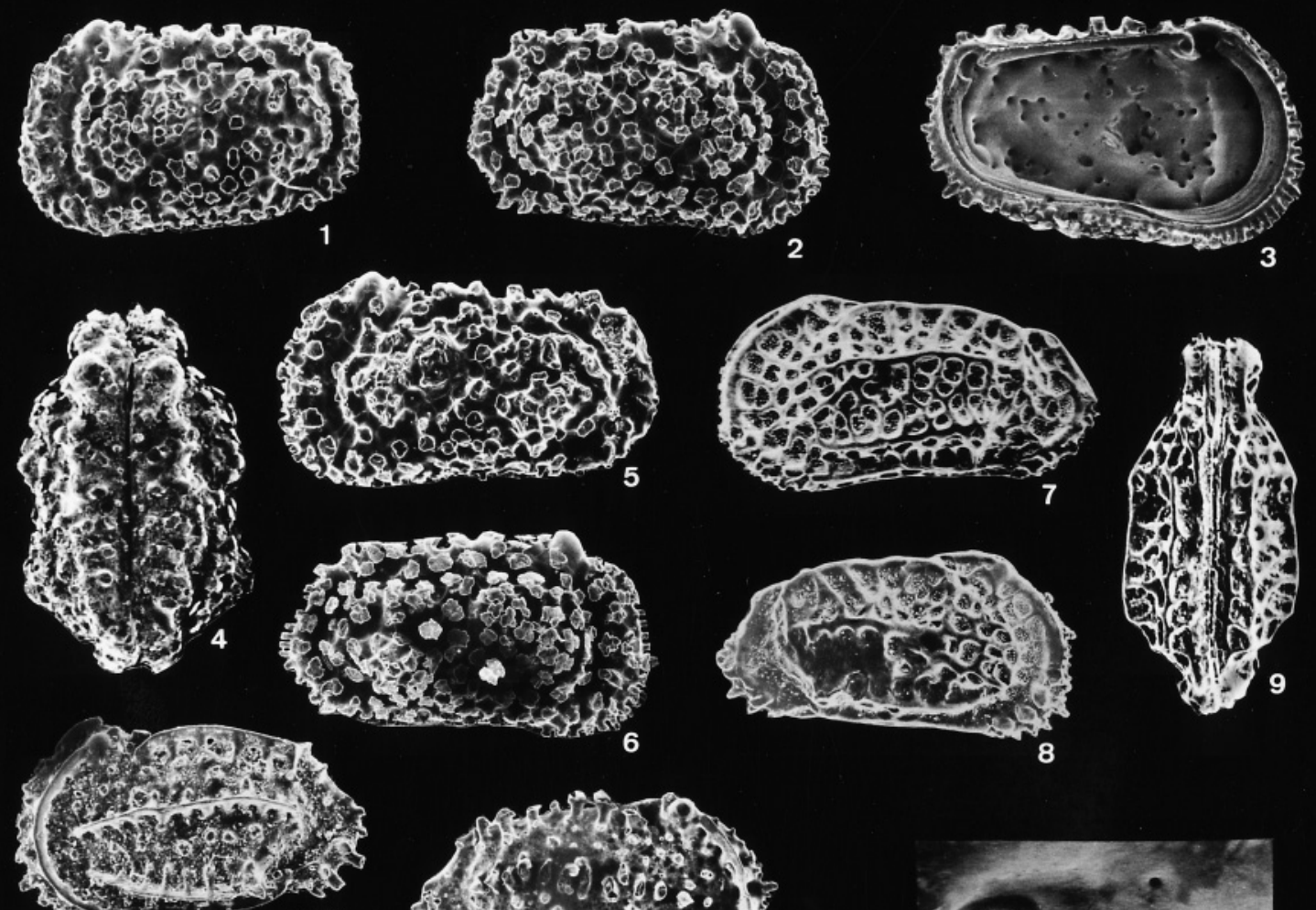

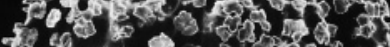

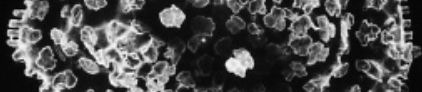

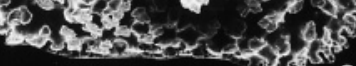

6
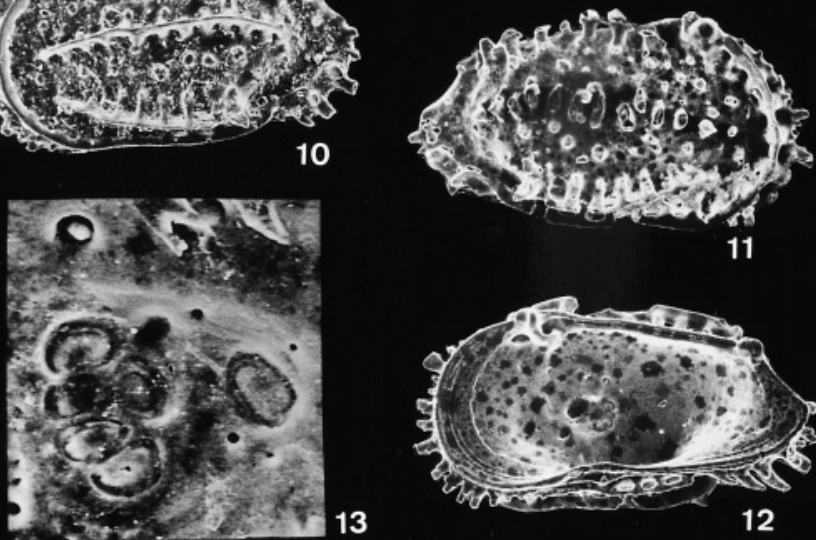

10

13
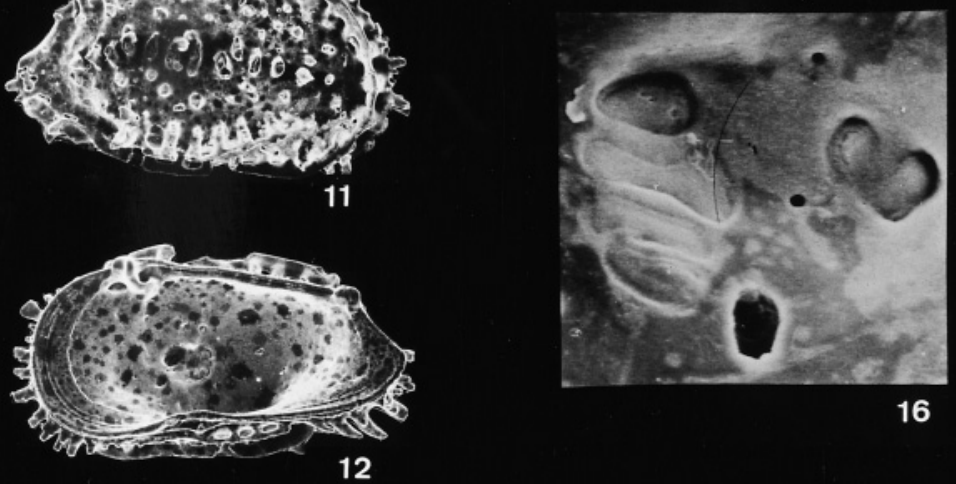

16
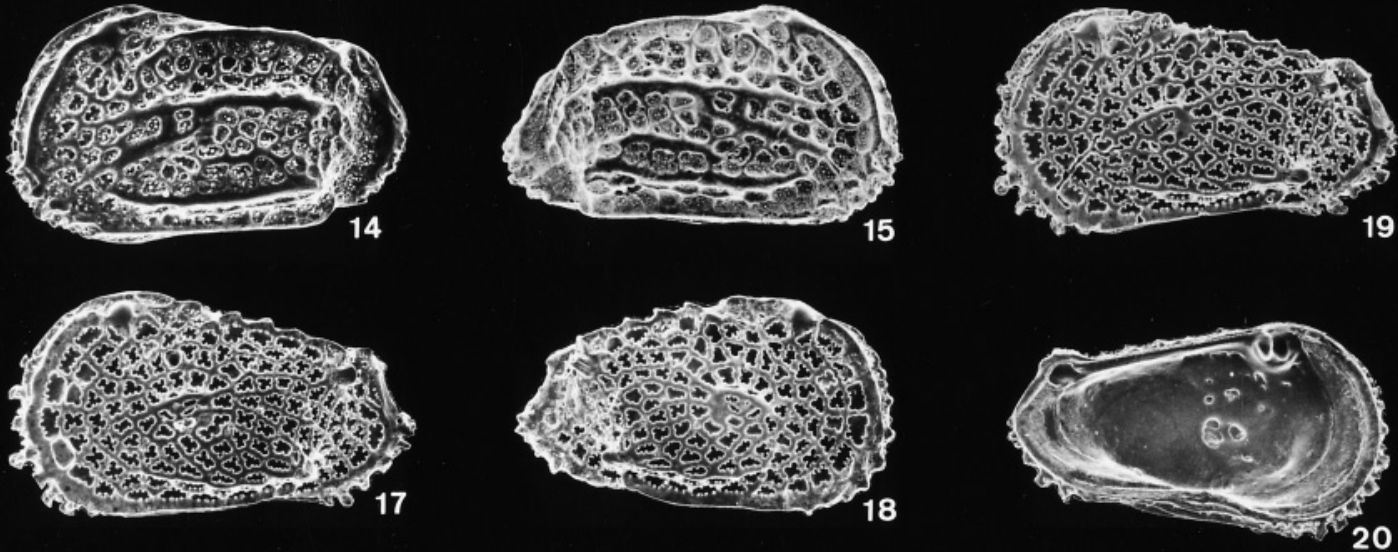
Description. Similar in shape and outline to the nominate sub-species but with the antero-marginal rib embellished by three prominent nodes and blunt marginal denticles. The median, dorsal and ventro-lateral ribs are all strongly developed with the former characteristically birfurcating at approximately the position of the adductor muscle scars, and the latter being a sub-alar projection postero-ventrally. The bifurcations of the median rib become lost in coarse reticulation anteriorly and the dorsal rib is sinuous due to 'erosion' by the strong intercostal reticulation. These ribs are connected posteriorly by a dorsal and a ventral loop. Intercostal areas strongly reticulate, the reticulae somewhat 'eroding' the dorsal rib. Reticulae with numerous minute papillae. Internal features as for species. Sexual dimorphism not developed.

\section{Dimensions (mm).}

$\begin{array}{llc} & \text { Length } & \text { Height } \\ \text { Holotype } & & \\ \text { LV, MP-O-1765 } & 0.74 & 0.39 \\ \text { Paratypes } & & \\ \text { RV, MP-O-1766 } & 0.72 & 0.36 \\ \text { C, MP-O-1767 } & 0.74 & 0.39\end{array}$

Distribution. Recent sediments from the Brazilian Equatorial Shelf, northeast of the mouth of the River Amazon. In the present study it occurred in the following samples: Leg $5 \mathrm{~A}$, sample 3568; Geomar II, samples 97, 99, 106, 108, 109, 111, 119, $166,180,182,185,186,187,188,191,198,202,203,204,209$, 210, 212, 1500, 2476, 2522.

Remarks. This sub-species is probably closest to Costa variabilicostata muhlemani Van den Bold, 1966a, but differs in possessing three nodes antero-ventrally.

\section{Costa variabilicosta aff. C. v. recticostata Bold, 1970}

$$
\text { (Pl. 1, figs 14-16) }
$$

1963 Costa variabilicostata (Bold); Bold: 370, table 6.

1964 Costa variabilicostata (Bold); Bold: 9-11.

1966 Costa variabilicostata variabilicostata (Bold); Baker \& Hulings: 116, pl. 2, fig. 4.

1966a Costa variabilicostata variabilicostata (Bold); Bold: 183, pl. 22, fig. 5.

1966b Costa variabilicostata variabilicostata (Bold); Bold: pl. 1,

figs $10 \mathrm{a}-\mathrm{b}$.

1966c Costa variabilicostata (Bold); Bold: 10, table 1; 11, table 2; 27.

1970 Costa variabilicostata recticostata Bold; Bold: 68, fig. 1, pl. 1, figs $4 \mathrm{a}-\mathrm{d}$.
1975 Costa variabilicostata recticostata Bold; Teeter: 456, figs $14 \mathrm{~b}, 15 \mathrm{~d}$.

1988b Costa variabilicostata recticostata Bold; Bold: 146, 150, 154, tables 1, 2.

Material. Abundant.

\section{Dimensions (mm).}

Homotypes

Female LV, MP-O-1771 $\quad 0.67 \quad 0.39$

Female RV, MP-O-1772 $\quad 0.66 \quad 0.37$

Distribution. Previously recorded from the Upper Miocene of Colombia (Tubara Fm.), the Pleistocene? of Costa Rica (Moin Fm.) and the Recent of Trinidad, Venezuela, Colombia, Belize, Lesser Antilles and Puerto Rico. In the present study it occurs in LEG 5, samples 3459, 3477; Geomar I, samples 8, 11, 21, 33, 34; Geomar II, samples 105, 2447; Geomar III, samples 188, 189, 190, 199, 200, 2471.

Remarks. This sub-species was first described by Bold (1970) from Costa Rica and has been widely recorded subsequently as one or other of two sub-species from the Gulf of Mexico, Caribbean region. The authors suggest tentatively that the present material species is most closely related to the sub-species recticostata because, although it is very similar to Costa variabilicostata variabilicostata Bold, 1950, the presence of reticulation in front of the anterior sub-marginal rib; sub-rectilinear dorsal, central and ventral ribs; and the presence of sexual dimorphism clearly favours the former sub-species. Bold (1970) found specimens larger $(0.71-0.75 \mathrm{~mm})$ than the specimens from the type-locality, on the North Trinidad Shelf at depths between $54 \mathrm{~m}$ and $86 \mathrm{~m}$. The adult specimens in the present material are also larger than those from Costa Rica but do not reach $0.7 \mathrm{~mm}$.

Genus Cativella Coryell \& Fields, 1937

Cativella paratranslucens sp. nov. (P1. 1, figs 10-13)

Derivation of name. L. Named for the superficial similarity of this species to Cativella semitranslucens (Crouch, 1949).

Diagnosis. A species of Cativella with three distinctly ponticulate ribs and tuberculate intercostal areas. The median rib does not extend to the anterior rib.

\section{Explanation of Plate 1.}

figs 1-6. Henryhowella tuberculoclaviforma sp. nov.: 1, female left valve, external lateral view, $\times 121$, MP-O-1760; 2, female right valve, external lateral view, $\times 126$, MP-O-1761 (holotype); 3, female left valve, internal view, $\times 132$, MP-O-1760; 4, female carapace, dorsal view, $\times 132$, MP-O-1762; 5, male left valve, external lateral view, $\times 123$; MP-O-1763; 6, male right valve, lateral external view, $\times 117$, MP-O-1764. figs 7-9. Costa variabilicostata brasiliensis ssp. nov.: 7, left valve, external lateral view, $\times 217$, MP-O-1765 (holotype); 8, right valve, external lateral view, $\times 201$, MP-O-1766; 9, carapace, dorsal view, $\times 210$, MP-O-1767. figs 10-13. Cativella paratranslucens sp. nov.: 10, female left valve, external lateral view, $\times 135$, MP-O-1768 (holotype); 11, female right valve, external lateral view, $\times 135$, MP-O-1769; 12, female right valve, internal view, $\times 135$, MP-O-1770; 13, female left valve, detail of central muscle scars, $\times 235$, MP-O-1768. figs 14-16. Costa variabilicostata aff. recticostata Bold, 1970: 14, female left valve, external lateral view, $\times 162$, MP-O-1771; 15, female right valve, lateral external view, $\times 162$, MP-O-1772; 16, female left valve, central muscle scars, $\times 264$, MP-O-1771. figs 17-20. Cletocythereis atlantica sp. nov.: 17, female left valve, external lateral view, $\times 150$, MP-O-1773; 18, female right valve, external lateral view, $\times 150$, MP-O-1774 (holotype); 19, male left valve, external lateral view, $\times 150$, MP-O-1775; 20, female left valve, internal view, $\times 150$, MP-O-1776. 


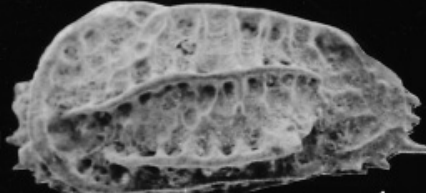

1
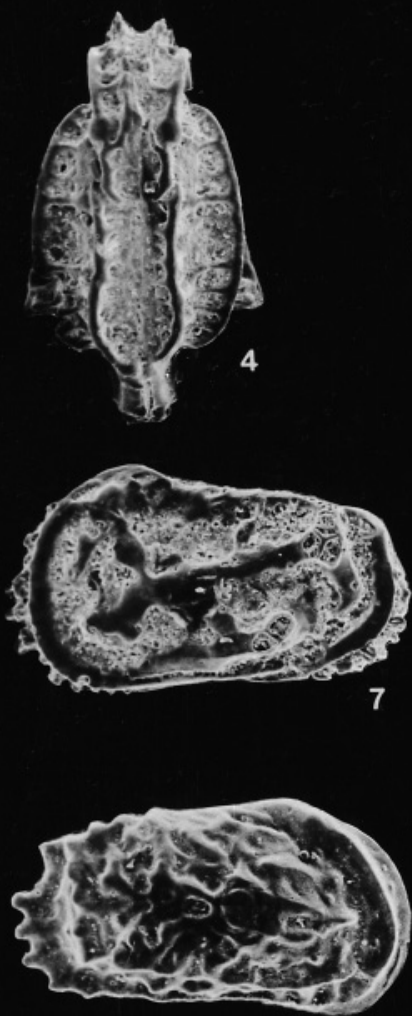

10
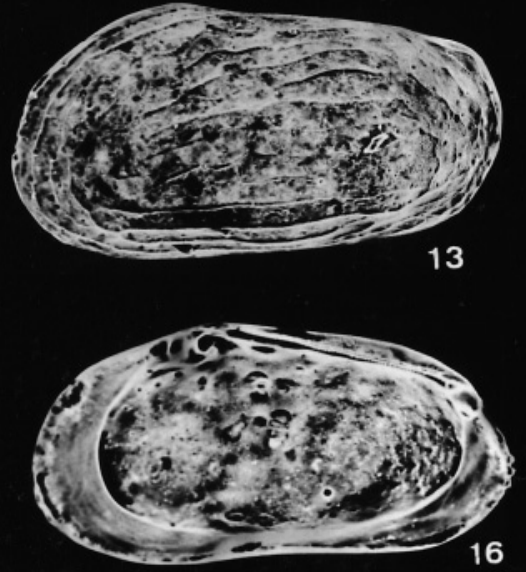
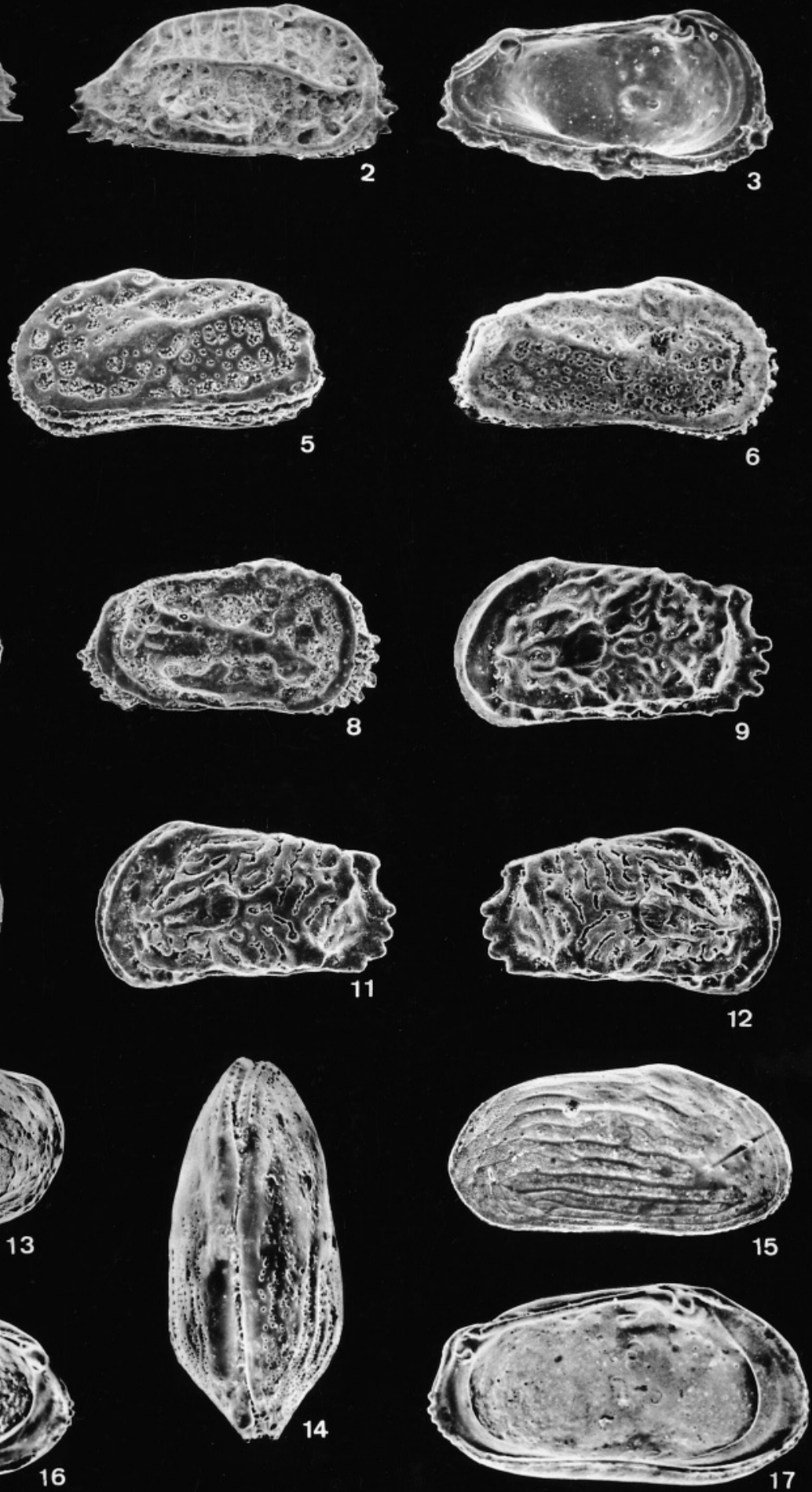
Holotype. Female LV, MP-O-1768.

Material. Common.

Locality and horizon. Project REMAC, Leg 6, sample 3685, lat. $02^{\circ} 12^{\prime} \mathrm{S}$-long. $40^{\circ} 20^{\prime} \mathrm{W}, 49 \mathrm{~m}$. Recent.

Description. Large. Shell of medium thickness. Carapace subrectangular in lateral view. Anterior margin broadly rounded but rendered angular by its marginal denticles and flange. Posterior margin with one postero-dorsal and three posteroventral spines and blunt apex just below mid-height. Dorsal margin straight and inclined slightly towards the posterior; largely obscured by the convex dorsal rib. Ventral margin slightly sinuous. Valves convex in dorsal view and anterior margin strongly rimmed. Ornament costate and tuberculate. From a distinct dorsal loop, which is not connected to the median rib, the dorsal rib extends in an arcuate manner, above the dorsal margin, to its termination behind the eye. The median rib extends across the valve from a mid posterolateral to a mid antero-lateral position. The ventro-lateral rib increases in height posteriorly; five small riblets extend dorsally from this. All these ribs are ponticulate. From the distinct eye tubercle, a short arcuate rib extends posteriorly and another, longer rib parallels the anterior margin to its antero-ventral termination. Intercostal areas smooth with intermittent tubercles of different sizes; a distinct row of large tubercles bisects and parallels the median and ventro-lateral ribs. Internal characters as for the genus. Sexual dimorphism not strongly marked; males a little lower and longer than females.

Dimensions (mm).

$\begin{array}{llc} & \text { Length } & \text { Heigh } \\ \text { Holotype } & & \\ \begin{array}{l}\text { Female LV, MP-O-1768 } \\ \text { Paratype }\end{array} & 0.77 & 0.43 \\ \text { Female RV, MP-O-1769 } & 0.79 & 0.42 \\ \text { Female RV, MP-O-1770 } & 0.77 & 0.42\end{array}$

Distribution. Equatorial Shelf of Brazil. Leg 5, sample 3477; Leg 5A, sample 3567; Leg 6, samples 3635, 3672, 3685, 3692, 3717; Geomar I, samples 8, 11; Geomar II, samples 97, 99, 109, 111, 120, 128; Geomar III, samples 146, 154, 166, 180, 184, 185, 186, 188, 191, 198, 202, 204, 209, 210, 217, 2471, 2500, 2522.

Remarks. Some specimens have the dorsal and anterior ribs united. The present species differs from C. semitranslucens (Crouch, 1949) by virtue of its ponticulate ribs.
Cativella reticulocostata $\mathrm{sp}$. nov.

(P1. 2, figs 1-4)

Derivation of name. L. From the combination of ribs and reticulae which form the ornament of this species.

Diagnosis. A slender, rather elongate species of Cativella with strong ribs and intercostal reticulae in which the vertical muri predominate.

\section{Holotype. LV, MP-O-1777.}

Material. Frequent.

Locality and horizon. Project REMAC, Leg 6, sample 3684, lat. $02^{\circ} 19^{\prime} \mathrm{S}$-long. $40^{\circ} 21^{\prime} \mathrm{W}, 33 \mathrm{~m}$. Recent.

Description. Large. Fairly thick-shelled. Subhastate in dorsal view. Carapace elongate, subpyriform in lateral view and strongly acuminate posteriorly. Anterior margin well-rounded with strong flange and marginal denticles antero-ventrally. Posterior margin pointed, especially in RV with apex just below mid-height and with strong marginal denticles below. Dorsal margin straight and sloping towards the posterior. Ventral margin largely obscured by valve tumidity. End margins paralleled by strong marginal rib; the same rib also extending along the ventral margin and, in a slightly arcuate manner along the dorsal margin to its termination just behind the eye tubercle, which is situated on the antero-marginal rib. Intercostal areas strongly reticulate. The vertical components of the muri predominating. Internal characters as for genus. Sexual dimorphism not developed.

\section{Dimensions (mm).}

Holotype

LV, MP-O-1777 $\quad 0.75$

Length Height

Paratypes

$\begin{array}{lll}\mathrm{RV}, \text { MP-O-1778 } & 0.77 & 0.34\end{array}$

LV, MP-O-1779 $0.74 \quad 0.39$

$\begin{array}{lll}\text { C, MP-O-1780 } & 0.74 & 0.42\end{array}$

Distribution. Recent sediments from the Equatorial Shelf of Brazil. Leg 5, samples 3459, 3477; Leg 6, sample 3684; Geomar I, samples 21, 24, 34; Geomar II, samples 99, 108, 113, 209, 210, 2466, 2475.

Remarks. This species differs from Cativella iyemojai Omatsola 1972, from West Africa, mainly in its shorter median and

Explanation of Plate 2.

figs 1-4. Cativella reticulocostata sp. nov.: 1, left valve, external lateral view, $\times 120$, MP-O-1777 (holotype); 2 , right valve, external lateral view, $\times 120$, MP-O-1778; 3, left valve, internal view, $\times 120$, MP-O-1779; 4, carapace, dorsal view, $\times 120$, MP-O-1780. figs 5-6. Neocaudites subimpressus (Edwards, 1944): 5, female carapace, external lateral view, $\times 162$, MP-O-1781; 6, male carapace, external lateral view, $\times 162$, MP-O-1782. figs 7-8. Neocaudites triplistriatus (Edwards, 1944): 7, female left valve, external lateral view, $\times 160$, MP-O-1783; 8, female right valve, external lateral view, $\times$ 160, MP-O-1784. figs 9-10. Puriana variabilis Chukewiski \& Purper, 1985a: 9, female left valve, external lateral view, $\times 190$, MP-O-1785; 10, female right valve, external lateral view, $\times 190$, MP-O-1786. figs 11-12. Puriana convoluta Teeter, 1975: 11, female left valve, external lateral view, $\times$ 190, MP-O-1787; 12, female right valve, external lateral view, $\times 190$, MP-O-1788. figs 13-17. Australimoosella polypleuron sp. nov.: 13, left valve, external lateral view, $\times 198$, MP-O-1789; 14, carapace, dorsal view, $\times 205$, MP-O-1790; 15, right valve, external lateral view, $\times 165$, MP-O-1791 (holotype); 16, right valve, internal view, $\times 205$, MP-O-1793; 17, left valve, internal view, $\times 205$. MP-O-1792. 
ventro-lateral ribs, being less acuminate posteriorly, and its less strongly pronounced eye tubercle.

Genus Cletocythereis Swain, 1963

Cletocythereis atlantica sp. nov.

(P1. 1, figs 17-20)

Derivation of name. L. with reference to the fact that this is the first species of Cletocythereis described from the Atlantic Ocean.

Diagnosis. A species of Cletocythereis with sub-rectangular carapace, ornamented with 'trefoil' (sensu Sylvester-Bradley \& Benson, 1971) and 'quadrifoil' reticulation produced by celation, ribs and tubercles. Anterior rim smooth. Flat marginal denticles distributed in different planes on the anterior, anteroventral and postero-ventral margins.

Holotype. Female RV, MP-O-1774.

Material. Frequent.

Locality and horizon. Geomar III, sample 188 , lat. $3^{\circ} 47^{\prime} \mathrm{N}$ - long. $50^{\circ} 01^{\prime} \mathrm{W}, 88 \mathrm{~m}$. Recent.

Description. Large. Moderately thick-shelled. Sub-rectangular in lateral view. Anterior margin well-rounded with apex at about mid-height. Posterior acuminate at mid-height in LV, below mid-height in RV. Dorsal margin straight but appearing irregular due to the over-reach of the dorsal ornament inclined towards the posterior and rendered slightly irregular by the surface ornament. Ventral margin straight in lateral view but with wide oral incurvature in internal view; convergent posteriorly. Anterior and postero-ventral margins embellished with flat marginal denticles in a number of planes. Ornament of trefoil and quadrifoil reticulation brought about by celation, distributed in a somewhat radiate pattern about the sub-central tubercle. Some muri of the reticulum are sufficiently strongly developed to become discrete ribs, especially ventro-laterally. Some ribs bear small spinose tuberculae. A salient marginal rib extends from the eye tubercle around the anterior and ventral margins, with a less well defined rib occurring around the dorsal and posterior margins. A distinct node occurs postero-dorsally and a sub-alar spine occurs postero-ventrally. Subcentral tubercle not salient and this area is traversed by a short, oblique rib. Internal features typical of the genus. Median element of holamphidont hinge in LV strongly buttressed internally, as is the anterior terminal element. Central muscle scars with four long scars in a vertical row. 'V'-shaped frontal scar. Sexual dimorphism distinct; males more elongate than females.

\section{Dimensions (mm).}

Holotype

Female RV, MP-O-1774 $\quad 0.75$

Paratypes

Female LV, MP-O-1773
Female LV, MP-O-1776

Male LV, MP-O-1775

Distribution. Occurring in Recent sediments from the Brazilian Equatorial Shelf, northeast of the mouth of the River Amazon. Geomar II, sample 105; Geomar III, samples 188, 189, 190.

Remarks. Cletocythereis atlantica sp. nov. is similar to Cletocythereis bradyi Holden, 1967 from the Indo-Pacific, but differs mainly in lacking small perpendicular fossae on the anterior margin.

\section{Genus Cletocythereis Swain, 1963}

Neocaudites subimpressus (Edwards, 1944)

(Pl. 2, figs 5-6)

1944 Cythereis subimpressa Edwards: 523, pl. 87, figs 29, 30. 1971 Neocaudites pacifica Allison \& Holden: 201, figs 26a-e. 1971 Neocaudites pacifica minima Allison \& Holden: 202, figs $26 \mathrm{f}-\mathrm{i}$.

1975 Neocaudites scottae Teeter: 455, figs 12j; 13k-m.

1983 Neocaudites subimpressus (Edwards); Hazel: 103, pl. 5, fig. 4.

1988 Neocaudites subimpressus (Edwards); Cronin: 884. 1988 Neocaudites pacifica Teeter; Cronin: 884.

1988a Neocaudites scottae Teeter; Bold: 40, p. 3, fig. 14. 1993 Falsocythere subimpressus (Edwards); Witte: 49.

1999a Neocaudites subimpressus (Edwards); Coimbra et al:: 377.

Material. Abundant.

\section{Dimensions (mm).}

Homotypes

Female C, MP-O-1781 $\quad 0.58 \quad 0.30$

Male C, MP-O-1782

0.60

0.29

Distribution. Previously recorded from the Pliocene of North Carolina (USA), the Pliocene to Recent of Cuba, the Dominican Republic and Costa Rica, the Recent of Clipperton Island (Eastern Pacific) and Belize. In the present study it was found in the following samples: Leg 4, sample 3391; Leg 6, samples 3607, 3608, 3609, 3610, 3611, 3615, 3616, 3624, 3646, 3686, 3690, 3700, 3710, 3721, 3722; Geomar I, samples 8, 21, 22; Geomar II samples 97, 103, 105, 106, 108, 109, 111, 113, 115, 118, 119, 125, 129; Geomar III, samples, 153, 166, 169, 180, 181, 182, 184, 185, 186, 187, 188, 189, 190, 191, 192, 198, 199, 200, 214, 218, 2469, $2471,2522,2528$

Remarks. Neocaudites subimpressus is very similar to $N$. terryi Holden, 1967, especially in the distribution of its punctation and reticulation. Both species exhibit a degree of intraspecific variation with respect to their ornament and size. Considering that the two species are widely distributed, occurring both in the Atlantic and the Pacific, it is probable that this variation is environmentally controlled, as suggested by Witte (1993). 
Taxonomy and zoogeography of Trachyleberididae, Brazil

Neocaudites triplistriatus (Edwards, 1944)

(P1. 2, figs 7-8)

Non 1951 Trachyleberis? cf. T.? triplistriata (Edwards); Swain: 37, pl. 6, figs 2, 3 .

1944 Cythereis triplistriatus Edwards: 522, pl. 87, figs 24-26.

1954 ? Trachyleberis aff. lauta (Brady); Keij: 222, pl. 4, fig. 11, pl. 6, fig. 9.

1954 Retrotrachyleberis cf. R. triplistriata (Edwards); Puri: 264, pl. 11, figs 1, 2 .

1963 Neocaudites triplistriatus (Edwards); Bold: 389, pl. 8, fig. 4. 1965 Costa triplistriata (Edwards); Hall: 33, pl. 7, figs 6, 9, 10.

1966 Neocaudites triplistriata (Edwards); Morales: 84, pl. 8, fig. 5 .

Non 1967 Neocaudites triplistriata (Edwards); Hulings: 654, text-figs $4 \mathrm{a}$, $7 \mathrm{i}$.

1968 Neocaudites triplistriatus (Edwards); Swain: D16, text-fig. 14, pl. 3, figs 1a-d.

1975 Neocaudites triplistriatus (Edwards); Bold: 148, pl. 17, fig. 11.

1977 Neocaudites triplistriatus (Edwards); Bold: 504, table 4.

1977 Neocaudites triplistriatus (Edwards); Hazel: 377, figs 3, 7d.

1983 Neocaudites triplistriatus (Edwards); Hazel: 104, pl. 6, fig. 1.

1988 Coquimba sp. 6. Dias-Brito, Moura \& Würdig: 481, pl. 2, fig. 33.

1992 Neocaudites triplistriatus (Edwards); Coimbra, Ramos \& Sanguinetti: pl. 1, fig. 18, tables 1-4.

Material. Rare.

\section{Dimensions (mm).}

Homotypes

Female LV, MP-O-1783 $\quad 0.55 \quad 0.30$

$\begin{array}{lll}\text { Female RV, MP-O-1784 } & 0.53 & 0.27\end{array}$

Distribution. This species is widely distributed in shallow marine waters from the NE coast of the USA to the coast of Rio de Janeiro State, Brazil and in a number of localities in the Caribbean. It occurs in the Upper Miocene of Florida and the Caribbean, the Pliocene of the Caribbean and the PlioPleistocene of Virginia and the Carolinas. In the present study it was found in Leg 5, sample 3455; Leg 6, sample 3718; Geomar III, samples 189, 190.

Remarks. This species is rather similar to Neocaudites nevianii Puri, 1960, N. atlantica Cronin, 1979 and N. variabilis Hazel, 1983. The morphological differences exhibited by these three species are clearly outlined by Witte (1993).

\section{Genus Puriana Coryell \& Fields, 1953}

Puriana variabilis Chukewiski \& Purper, 1985a

(P1. 2, figs 9-10)

1985a Puriana variabilis Chukewiski \& Purper: 314-316, pls 2-6. 1985b Puriana variabilis Chukewiski \& Purper: 331, 332, 336, chart 1.

1992 Puriana variabilis Chukewiski \& Purper; Coimbra, Ramos \& Sanguinetti: 100, pl. 2, fig. 10, tables 1-4.
Material. Very abundant.

Dimensions (mm).

Homotypes

Female LV, MP-O-1785 $\quad 0.59 \quad 0.28$

Female RV, MP-O-1786 $\quad 0.60 \quad 0.30$

Distribution. This species seems to be restricted to the Equatorial Shelf of Brazil. In the present study it occurs in the following samples: Leg 4, samples 3391, 3396, 3404, 3419, 3444, 3445, 3459; Leg 6, samples 3622, 3624, 3625, 3635, 3636, 3637, 3646, 3652, 3674, 3677, 3678, 3679, 3680, 3684, 3689, 3692, 3698, 3699, 3704, 3709, 3710, 3711, 3716, 3717, 3718, 3719, 3721, 3722, 3726, 3727, 3731, 3736, 3737, 3740, 3747, 3750: Geomar I, samples 6, 8, 11, 17, 19, 33, 38; Geomar II, samples 99, 109, 129; Geomar III, samples 141, 146, 147, 149, 155, 169, 2465, 2467, 2475, 2531.

\section{Puriana convoluta Teeter, 1975}

(P1. 2, figs 11-12)

1971 Puriana sp. B Valentine: D8.

1975 Puriana convoluta Teeter: 458, figs 14E, 15H-J.

1977 Puriana convoluta Teeter; Hazel: 386, fig. 8f.

1979 Puriana convoluta Teeter; Cronin: 147, pl. 16, fig. 8.

1983 Puriana convoluta Teeter; Hazel: 88, pl. 26, figs 1-4.

1983 Puriana convoluta Teeter; Palacios-Fest, Gío-Argaéz \& Krutak: table 1.

1985b Puriana convoluta Teeter; Chukewiski \& Purper: 313, 314, pl. 1, figs 1-6.

1988b Puriana convoluta Teeter; Bold: 146, 150, 155, tables 1, 2. 1990 Puriana convoluta Teeter; Machain-Castillo, PérezGuzmán \& Maddocks: 349, 350, table 2.

Material. Frequent.

Dimensions (mm).

Homotypes

Female LV, MP-O-1787 $\quad 0.48 \quad 0.26$

$\begin{array}{lll}\text { Female RV, MP-O-1788 } & 0.50 & 0.27\end{array}$

Distribution. Plio-Pleistocene, North Carolina; Recent. Florida, Texas, Gulf of Mexico, Belize, the Caribbean and southeast to the mouth of the River Amazon. In the present study the species occurs in the following samples: Leg 4, sample 3396; Leg 6, samples 3612, 3616, 3700, 3706, 3721, 3737; Geomar III, sample 2465.

Tribe Moosellini Hartmann, 1978 Genus Australimoosella Hartmann, 1978

Australimoosella polypleuron sp. nov.

(P1. 2, figs 13-17)

1999a gen. et sp. indet. 1 Coimbra et al.: 370, pl. 2, fig. 2, table 1

Derivation of name. Gr. $\pi \circ \lambda v$, meaning 'many', plus $\pi \lambda \varepsilon v \rho o v$, meaning 'ribs', i.e. $\pi \circ \lambda v \pi \lambda \varepsilon v \rho o v$ 'many ribs'. With reference to the numerous longitudinal ribs which constitute the principal ornament on the lateral surface of this species. 
Diagnosis. A species of Australimoosella ornamented with numerous rather weak longitudinal ribs on the lateral surface, slightly reticulate in the posterior region. Secondary ornament punctate.

Holotype. Female RV, MP-O-1791.

Material. Common.

Locality and horizon. Projeto REMAC, LEG 6, sample 3692, lat. $2^{\circ} 21^{\prime} \mathrm{N}$-long. $41^{\circ} 24^{\prime} \mathrm{W}, 37 \mathrm{~m}$. Recent.

Description. Medium, moderately thick-shelled carapace. Subovate in lateral view. Anterior margin rounded. Posterior margin slightly rounded, angled medially. Dorsal margin sinuous, stepped posteriorly, with prominent posterior cardinal ear. Ventral margin slightly concave medially. Posterior cardinal angle salient. Right valve smaller than left. Ornament with numerous, rather weak and parallel horizontal ribs on the lateral surface. Three narrow anterior ribs extend from the anterodorsal margin to the postero-ventral margin. Posterior region slightly reticulate. Intercostal areas sparsely punctate. Anteromedian region moderately celated. Normal pore canals located in the muri, regularly distributed over entire surface. In dorsal view, both valves are parallel, slightly flat in central region, inflated in the posterior region. Internal view: hinge holamphidont with median bar finely crenulated; frontal muscle scar in V-shape followed by four muscle scars in a vertical row. Sexual dimorphism inconspicuous.

Dimensions (mm).

$\begin{array}{lll}\text { Holotype } & \text { Length } & \text { Height } \\ \text { RV, MP-O-1791 } & 0.67 & 0.35 \\ \text { Paratypes } & & \\ \text { LV, MP-O-1789 } & 0.67 & 0.35 \\ \text { C, MP-O-1790 } & 0.68 & 0.38 \\ \text { LV, MP-O-1792 } & 0.67 & 0.36 \\ \text { RV, MP-O-1793 } & 0.66 & 0.35\end{array}$

Distribution. In the present study this species occurs in the following samples: Leg 6, samples 3637, 3672, 3677, 3692, 3616, 3617; Geomar I, samples 8, 17. This species seems to be restricted to the equatorial shelf to the $\mathrm{SW}$ of the mouth of the River Amazon.

Remarks. Australimoosella polypleuron sp. nov. resembles $A$. tomokoae (Ishizaki, 1968) in general outline and surface ornamentation, but differs in details of ornamentation, especially in the number of longitudinal ribs. The Brazilian specimens are smaller than those from Japan. Besides, the holotype of $A$. tomokoae has four adductor muscle scars not well described, the middle two of which appear to be subdivided, whereas $A$. polypleuron sp. nov. has all adductor muscle scars undivided.

\section{ZOOGEOGRAPHICAL AND STRATIGRAPHICAL DISTRIBUTIONS}

The zoogeographical distribution of ostracods from the Brazilian Equatorial Continental Shelf is radically influenced by the estuary of the Amazon/Pará rivers. The great influence of this estuary changes the physico-chemical characteristics of the adjacent oceanic area and this is reflected in the distribution of the fauna.

The discharge of the Amazon River is a huge mass of fluvial water of about $350000 \mathrm{~m}^{3} \mathrm{~s}^{-1}$ into the Atlantic Ocean and $11-13 \times 10^{8}$ ton $\mathrm{a}^{-1}$ of sediments (Diégues, 1972; Meade, 1985). The inner shelf to the northeast of the estuary is the most affected area. In both the dry and rainy seasons, the flux of fluvial water is permanent and runs parallel to the coast from the $\mathrm{NE}$ to Cape Orange. The discharge of sediments from the coast to $c .40 \mathrm{~m}$ depth is mainly muddy (Martins \& Coutinho, 1981) due to the influence of the Amazon River, and the salinity is lower, especially in the rainy season; this is probably the reason for the absence of ostracods from this area. Directly offshore, in water deeper than some $40 \mathrm{~m}$ depth, because of the lower density of the freshwater, marine conditions begin to return to normal and ostracods are more abundant. The area from the Parnaíba River Delta (Piauí State) to Cape São Roque (Rio Grande do Norte State) is characterized by low freshwater input, which only becomes significant during floods. This, together with the shallow water shelf depths and the warm and semi-arid climate, reduces terrigenous sedimentation and encourages carbonate production (Summerhayes et al., 1975; Melo et al., 1975; Milliman, 1977).

Coimbra et al. (1999a,b) defined two zoogeographical units based on the distribution of the ostracods in the studied area. The Northwestern Unit (NW), from $47^{\circ} 30^{\prime} \mathrm{W}$ to $51^{\circ} \mathrm{W}$, embraces the area between the Cape Orange and the mouth of the Amazon/Para rivers and is represented by 12 species which are restricted to this area, whereas the Southeastern Unit (SE), between $34^{\circ} 30^{\prime} \mathrm{W}$ to $48^{\circ} \mathrm{W}$, from the mouth of the Amazon/ Para rivers to the Cape São Roque has 16 endemic species. The remaining 46 species are pandemic to the studied area and prefer shallow waters and biodetritic sands.

In the present study, the NW unit is represented by two rare trachyleberidid species: Cletocythereis atlantica and Costa variabilicostata brasiliensis, occurring between depths of $50 \mathrm{~m}$ and $100 \mathrm{~m}$. The SE unit is represented by three species, which are more abundant in the epineritic zone $(<40 \mathrm{~m})$ : Puriana convoluta, P. variabilis and Australimoosella polypleuron sp. nov. (Fig. 2).

Pandemic Trachyleberididae in the study are: Costa variabilicostata aff. reticostata, Henryhowella tuberculoclaviforma, Cativella paratranslucens, C. reticulocostata, Neocaudites subimpressus and $N$. triplistriatus. All, except the latter which is very rare, are abundant species. H. tuberculoclaviforma, C. reticulocostata and $N$. triplistriatus occur on biodetrital sand at $75 \mathrm{~m}$, while $C$. variabilicostata aff. reticostata, C. paratranslucens and $N$. subimpressus occur also on biodetritic sand but at depths between $50 \mathrm{~m}$ and $100 \mathrm{~m}$ (Fig. 2).

Most of the genera representing these assemblages originated in the Neogene. Cletocythereis atlantica is the first species, of this genus, to be formally described in the Atlantic Ocean. The only prior record of this genus in the Atlantic waters is by Witte (1993), Cletocythereis? sp., from the Senegalese coast.

$P$. convoluta, $N$. triplistriatus and $N$. subimpressus seem to have first appeared in the Pliocene of North Carolina and migrated to the Caribbean and South America. The 
occurrence of Neocaudites subimpressus in Recent sediments from Clipperton Islands (Allison \& Holden, 1971), in the Eastern Pacific, is probably due to migration through the Neogene Straits of Panama, prior to the formation of the modern isthmus.

\section{CONCLUSIONS}

The study of the family Trachyleberididae in the Equatorial Brazilian Continental Shelf yielded five new species: Cletocythereis atlantica, Cativella paratranslucens, C. reticulocostata, Henryhowella tuberculoclaviforma and Australimoosella polypleuron. Two sub-species were attributed to the Costa 'variabilicostata' group: Costa variabilicostata brasiliensis subsp. nov. and Costa variabilicostata aff. recticostata Bold, 1970 and four others species were recognized: Neocaudites subimpressus, $N$. triplistriatus Edwards (1944), Puriana convoluta Teeter (1975) and P. variabilis Chukewisky \& Purper (1985a).

On the basis of the geographical distribution of the studied species, two assemblages are recognized. The NW assemblage, represented by two rare species restricted to this area, is the region most affected by the Amazon River discharge, especially at the inner shelf (c. $40 \mathrm{~m}$ depth). The SE assemblage, represented by three rare species restricted to this area, is the least affected area and ostracods are more abundant in the epineritic zone ( $<40 \mathrm{~m}$ depth). Most of the trachyleberidid genera studied here have their origins in the Neogene and are well distributed in shallow marine waters.

\section{ACKNOWLEDGEMENTS}

The authors are indebted to Petróleo Brasileiro S. A. and the Diretoria de Hidrografia e Navegação da Marinha do Brasil who provided the surface samples of this study; greatly indebted to Dr Ana Luisa Carreño (UNAM/México) and two anonymous referees for their suggestions and criticism. Also, thanks are extended to Mr Luis Flávio P. Lopes at UFRGS, for his help with photography. The first author gratefully acknowledges the CNPq (Conselho Nacional de Desenvolvimento Científico e Tecnológico) grants 520309/99-5 and 475313/03-08.

\section{Manuscript received 1 December 2002 Manuscript accepted 12 January 2004}

\section{REFERENCES}

Allison, E.C. \& Holden, J.C. 1971. Recent ostracodes from Clipperton Island, Eastern Tropical Pacific. Transactions of the San Diego Society of Natural History, 16(7): 165-214.

Baker, J.H. \& Hulings, N. 1966. Recent marine ostracod assemblages of Puerto Rico. Institute of Marine Science, 11: 108-125.

Bold, W.A. Van den 1950. Miocene Ostracoda from Venezuela. Journal of Paleontology, 24(1): 76-88.

Bold, W.A. Van den 1963. Upper Miocene and Pliocene Ostracoda of Trinidad. Micropaleontology, 9(4): 361-424.

Bold, W.A. Van den 1964. Nota preliminar sobre los ostrácodos del Mioceno-Reciente de Venezuela. Geos, 11: 7-18.

Bold, W.A. Van den 1966a. Ostracoda of the Pozón Section, Falcón, Venezuela. Journal of Paleontology, 40(1): 177-185.

Bold, W.A. Van den 1966b. Ostracoda from Colon Harbor, Panama. Caribbean Journal of Science, 6(1-2): 43-64.

Bold, W.A. Van den 1966c. Miocene and Pliocene Ostracoda from northeastern, Venezuela. Verhandelingen der Koninklijke Nederlandse Akademie van Wetenschappen, Afd. Natuurkunde, part 1, 23(3): 1-43.
Bold, W.A. Van den 1970. The genus Costa (Ostracoda) in the Upper Cenozoic of the Caribbean Region. Micropaleontology, 16(1): 61-75.

Bold, W.A. Van den 1975. Ostracodes from the Late Neogene of Cuba. Bulletins of American Paleontology, 68(289): 121-167.

Bold, W.A. Van den 1977. Cenozoic marine Ostracoda of the South Atlantic. In: Swain, F.M. (Ed.), Stratigraphic micropaleontology of Atlantic basin and borderlands. Elsevier, Amsterdam, 495-519.

Bold, W.A. Van den 1988a. Neogene paleontology in the northern Dominican Republic 7. The Subclass Ostracoda (Arthropoda: Crustacea). Bulletin of American Paleontology, 94(329): 1-105.

Bold, W.A. Van den 1988b. Ostracoda of the Alacran Reef, Campeche Shelf, Mexico. Tulane Studies in Geology and Paleontology, 21(4): $143-156$.

Brady, G.S. 1880. Report on the Ostracoda dredged by H.M.S. Challenger during the years 1873-1876. Report on the scientific results of the voyage of H.M.S. Challenger during the years 1873-1876, Zoology, 1(3): 1-184.

Carmo, D.A. do \& Sanguinetti, Y.T. 1995. Krithe occurrence on the Brazilian continental margin: An ecological approach. In: Ríha, J. (Ed.), Ostracoda and Biostratigraphy. Balkema, Rotterdam, 407-412.

Chukewiski, K. \& Purper, I. 1985a. A new ostracode Puriana variabilis Chukewiski Purper, sp. nov. from Brazilian coast. Anais, $2^{\circ}$ Simpósio de Geologia da Amazônia, Belém, SBG, 2: 312-326.

Chukewiski, K. \& Purper, I. 1985b. Occurrence of Puriana (Ostracoda) in the Brazilian continental shelf: its ecology, geographical and stratigraphical distribution. Anais, $2^{\circ}$ Simpósio de Geologia da Amazônia, Belém, SBG, 2: 327-339.

Coimbra, J.C. \& Carmo, D.A. do 2002. Taxonomy and ecology of Cornucoquimba ramosae sp. nov. (Ostracoda, Crustacea) on the Brazilian Equatorial shelf. Journal of Micropalaeontology, 21: 23-27.

Coimbra, J.C. \& Carreño, A.L. 2002. Sub-Recent Bairdiinae (Crustacea, Ostracoda) from the Brazilian Equatorial Shelf. Revista Española de Micropaleontología, 34(2): 187-199.

Coimbra, J.C. \& Fauth, G. 2002. The families Bythocytheridae Sars, 1866 and Pectocytheridae Hanai, 1957 (Ostracoda) on the Brazilian equatorial shelf. Neues Jahrbuch für Geologie und Paläontologie, 9: 562-576.

Coimbra, J.C. \& Ornellas, L.P. 1986. The subfamily Orionininae Puri, 1973 (Ostracoda, Hemicytheridae) in the Brazilian continental shelf. Part I. General considerations and systematic of the genus Orionina Puri, 1953. Anais, $34^{\circ}$ Congresso Brasileiro de Geologia, Goiânia, $S B G$, 1: 539-555.

Coimbra, J.C. \& Ornellas, L.P. 1987. The subfamily Orionininae Puri, 1973 (Ostracoda, Hemicytheridae) in the Brazilian continental shelf. Part II. Caudites Coryell \& Fields, 1937. Pesquisas, 19: 55-79.

Coimbra, J.C. \& Ornellas, L.P. 1989. Distribution and ecology of Sub-Recent Orionininae (Ostracoda) in the Brazilian continental shelf. Revista Brasileira de Geociências, 19(2): 177-186.

Coimbra, J.C., Ramos, M.I.F. \& Sanguinetti, Y.T. 1992. Sub-Recent otracodes of the Tamandare Bay, Northeastern Brazil - A preliminary report on biofacies. Pesquisas, 19(1): 94-105.

Coimbra, J.C., Sanguinetti, Y.T. \& Bittencourt-Calcagno, V. 1995. Taxonomy and distribution patterns of Recent species of Callistocythere Ruggieri, 1953 (Ostracoda) from the Brazilian continental shelf. Revista Española de Micropaleontología, 27(3): 117-136.

Coimbra, J.C., Pinto, I.D., Würdig, N. \& Carmo, D.A. do 1999a. Zoogeography of Holocene Podocopina (Ostracoda) from the Brazilian Equatorial shelf. Marine Micropaleontolology, 37: 365-379.

Coimbra, J.C., Carreño, A.L. \& Michelli, M.J. 1999b. Taxonomía y zoogeografía de la familia Cytheruridae (Ostracoda) de la plataforma continental ecuatorial de Brasil. Ilheringia, Série Zoologia, 87: $117-142$.

Cronin, T.M. 1979. Late Pleistocene marginal marine ostracodes from the southeastern atlantic coastal plain and their paleoenvironmental implications. Geographie Physique et Quaternaire, 33(2): 121-173.

Cronin, T.M. 1988. Geographical isolation in marine species: evolution and speciation in ostracods, I. In: Hanai, T., Ikeya, N. \& Ishizaki, K. (Eds), Evolutionary Biology of Ostracoda: its fundamentals and applications. Elsevier, Amsterdam, 871-889.

Crouch, R.W. 1949. Pliocene Ostracoda from Southern California. Journal of Paleontology, 23(6): 594-599. 
Dias-Brito, D., Moura, J.A. \& Würdig, N. 1988. Relationships between ecological models based on ostracods and foraminifers from Sepetiba Bay (Rio de Janeiro - Brazil). In: Hanai, T., Ikeya, N. \& Ishizaki, K. (Eds), Evolutionary Biology of Ostracoda: its fundamentals and applications. Elsevier, Amsterdam, 467-484.

Diégues, F.M.F. 1972. Introdução à oceanografia do estuário amazônico. Anais, 26: 301-318.

Edwards, R.A. 1944. Ostracoda from the Dublin Marl (Upper Miocene) of North Carolina. Journal of Paleontology, 18(6): 505-528.

Fauth, G. \& Coimbra, J.C. 1998. Zoogeography of the ostracode genera Auradilus and Radimella on the Brazilian continental shelf. Neues Jahrbuch für Geologie und Paläontologie, 8: 463-474.

Hall, D.D. 1965. Paleoecology and Taxonomy of fossil Ostracoda in the vicinity of Sapelo Island, Georgia. In: Kesling, R.V., Darby, D.G., Smith, R.N. \& Hall, D.D. (Eds), Four reports of ostracod investigations conducted under Nacional Science Foundation Project GB-26. Report no, 4: 1-79.

Hazel, J.E. 1977. Distribution of some biostratigraphically diagnostic ostracodes in the Pliocene and Lower Pleistocene of Virginia and northern North Carolina. US Geological Survey, Journal of Research, 5(3): 373-388

Hazel, J.E. 1983. Age and Correlation of the Yorktown (Pliocene and Pleistocene) formations at the Lee Creek Mine. In: Ray, C.E. (Ed.), Geology and Paleontology of the Lee Creek Mine, North Carolina. Smithsonian Contributions to Paleobiology, 53: 81-199.

Holden, J.C. 1967. Late Cenozoic ostracodes from the drowned terraces in the hawaiian islands. Pacific Science, 21(1): 1-50.

Hulings, N.C. 1967. A review of the Recent marine podocopid and platycopid ostracods of the Gulf of Mexico. Contributions to Marine Sciences, 12: 80-100.

Ishizaki, K. 1968. Ostracodes from the Uranouchi Bay, Kochi Prefecture, Japan. Science Reports of the Tohoku University 2nd ser. (Geol.), 40: $1-45$.

Keij, A. 1954. Distribution of faunal remains: microfauna. Ostracoda: identifications and descriptions of species. In: Andel, T.V. \& Postma, H. (Eds), Recent Sediments of the Gulf of Paria. Reports of the Orinoco Shelf Expedition, 1. North-Holland Publishing Company, Amsterdam, 117-134.

Kowsmann, R.O. \& Costa, M.P.A. 1979. Sedimentação quaternária da margem continental brasileira e das águas oceânicas adjacentes. Projeto REMAC - Reconhecimento Global da Margem Continental Brasileira, 8. Petrobrás, Cenpes, Dintep, Rio de Janeiro, 1-55.

Machain-Castillo, M.C., Pérez-Guzmán, A.M. \& Maddocks, R.F. 1990. Ostracoda of the terrigenous continental platform of the southern Gulf of Mexico. In: Whatley, R.C. \& Maybury, C. (Eds), Ostracoda and Global Events. Chapman \& Hall, London, 341-353.

Martins, I.R. 1984. Aspectos da oceanografia física do Atlântico Sul. Pesquisas, 16: 76-90.

Martins, L.R. 1974. Sedimentologia da margem continental amazônica. Tese de Livre-Docência. Instituto de Geociências, Universidade Federal do Rio Grande do Sul, 104pp.

Martins, L.R. \& Coutinho, P.N. 1981. The Brazilian Continental Margin. Earth-Science Reviews, 17: 87-107.

Martins, L.R., Urien, C.M., Butler, L.W. \& Martins, I.R. 1975. Morfologia e sedimentos da plataforma continental atlântica sul-america entre Cabo Orange e Chuí (Brasil). Anais de Hidrografia, 23: 83-109.

Meade, R.H. 1985. Suspended sediment in the Amazon River and its tributaries in Brazil during 1982-84. US Geological Survey, Open-file Report: 85-92.

Medeiros, M.A. \& Coimbra, J.C. 1989. Sub-Recent distribution of Kangarina Coryell \& Fields, 1937 (Crustacea; Ostracoda) in the Northern Brazilian Coast. Anais, $11^{\circ}$ Congresso Barsileiro de Paleontologia, Curitiba, SBP, 1: 479-491.
Melo, U., Summerhayes, C.P. \& Ellis, J.P. 1975. Upper continental margin sedimentation off Brazil. Contributions to Sedimentology, 4: $78-116$.

Milliman, J.D. 1977. Relict magnesian calcite oolite and subsidence of the Amazon shelf: reply. Sedimentology, 24: 149-151.

Morales, G.A. 1966. Ecology, distribution and taxonomy of Recent Ostracoda of the Laguna de Términos, Caampeche, Mexico. Boletín del Instituto de Geologia, Universidad Nacional Autónoma de Mexico, 81: $1-103$.

Omatsola, M.E. 1972. Recent and Sub-Recent Trachyleberididae and Hemicytheridae (Ostracoda, Crustacea) from the Western Niger Delta, Nigeria. Bulletin of the Geological Institution, University of Uppsala, 3(5): 37-120.

Ornellas, L.P. \& Coimbra, J.C. 1985. Occurrence of Pseudoceratina droogeri van den Bold, 1965 in the Northern Brazilian Continental Shelf. Anais, $2^{\circ}$ Simpósio de Geologia da Amazônia, Belém, SBG, 1: 396-407.

Palacios-Fest, M.R., Gío-Argaéz, R. \& Krutak, P.R. 1983. Los ostrácodos (Crustacea) Recientes del Caribe Mexicano y su significación faunística. Anais del Instituto de Ciencias del Mar y Limnología, Universidad Nacional Autónoma de México, 10(1): 195-201.

Puri, H.S. 1954. Contribution to the study of the Miocene of the Florida Panhaandle. Part 3: Ostracoda. Geological Bulletin, State of Florida, State Board of Conservation, Florida Geological Survey, 36: 215-345.

Puri, H.S. 1960. Recent Ostracoda from the west coast of Florida. Transactions of the Gulf Coast Association of Geological Societies, 10: 107-149.

Purper, I. \& Ornellas, L.P. 1987a. Paracytheridea tschoppi van den Bold, 1946 and its allied species, Paracytheridea batei Purper \& Ornellas, sp. nov. in the Brazilian continental shelf. Anais, $10^{\circ}$ Congresso Brasileiro de Paleontologia, Rio de Janeiro, SBP, 1: 747-759.

Purper, I. \& Ornellas, L.P. 1987b. The genus Paracytheridea (Ostracoda) in the Northern/Northwestern Brazilian continental shelf. Pesquisas, 20: $103-124$.

Ramos, M.I.F. 1994. The ostracod genus Coquimba Ohmert, 1968 from the Brazilian continental shelf. Revista Española de Micropaleontología, 26(3): 65-82.

Ramos, M.I.F. 1996. Taxonomy and zoogeography of the ostracod genera Nanocoquimba and Cornucoquimba Ohmert, 1968 from Recent sediments on the Brazilian continental shelf. Revista Española de Micropaleontología, 28(1): 105-128.

Summerhayes, C.P., Coutinho, P.N., França, A.M.C. \& Ellis, J.P. 1975. Upper continental margin sedimentation off Brazil: Part III Salvador to Fortaleza, northeastern Brazil. Contributions to Sedimentology, 4: 44-78.

Swain, F.M. 1951. Ostacoda from wells in North Carolina, Part 1, Cenozoic Ostracoda. US Geological Survey, Professional Paper, 234: $1-58$.

Swain, F.M. 1968. Ostracoda from the Upper Tertiary Waccamaw Formation of North Carolina and South Carolina. US Geological Survey, Professional Paper, 573: 1-37.

Sylvester-Bradley, P.C. \& Benson, R.H. 1971. Terminology for surface features in ornate ostracodes. Lethaia, 4(3): 249-286.

Teeter, J.W. 1975. Distribution of Holocene marine Ostracoda from Belize. In: Wantland, K.F. \& Pusey, W.C. (Eds), Belize shelf carbonate sediments, clastic sediments and ecology. American Association of Petroleum Geologists, Studies in Geology, 2: 400-499.

Valentine, P.C. 1971. Climatic implication of a Late Pleistocene ostracode assemblage from southeastern Virgínia. US Geological Survey, Professional Paper, 683: 1-28.

Witte, L.J. 1993. Taxonomy and biogeography of west African beach ostracods. Verhandelingen Koninklijke Nederlandse van Wetenschappen, Afd. Natuurkunde, Eerste Reeks deel, 39: 1-68. 